\title{
Pembuatan Aplikasi Sensus Penduduk Untuk Desa Wulunggunung
}

\author{
Teguh Hananto Widodo ${ }^{1)}$, Oky Dwi Nurhayati ${ }^{2}$, Ike Pertiwi Windasari ${ }^{2)}$ \\ Program Studi Sistem Komputer Fakultas Teknik Universitas Diponegoro \\ Jalan Prof. Sudharto, Tembalang, Semarang, Indonesia \\ teguhhanantowidodo@gmail.com
}

\begin{abstract}
Population is all of the people who lives in an area for more and less than 6 month, but aim to live in there for a long time. It require an accurate data regarding aspects of quantity and quality of the population to get a picture about condition of population in certain area.The level of accuracy of the data obtained strongly influence the accuracy of the analysis and prediction of demographic conditions.

Because of development of technology rapidly, the census is a proses of recording, calculation and publication of demographic data which carried out on all the permanent residents who lived in a particular region or country simultaneouslycarried out with the census application to be a storage for a valid data. This application can make a census population easier to create report and save a valid data of a particular region. This application is built using Delphi.

Applications census contains personal data of an area that the scope of development is still in the village scale. This application is Expected to be of little help in making a report and other purposes.
\end{abstract}

Keywords :Population, Census, Delphi.

\section{Pendahuluan}

erkembangan komputer dewasa ini telah mengalami

$\mathrm{P}$ banyak perubahan sangat pesat, seiring dengan kebutuhan manusia yang sangat banyak dan kompleks. Teknologi sangat berpengaruh pada semua sektor kehidupan, baik itu perusahaan, pendidikan, instansi negara, bahkan di dunia kerja. Sehingga banyak pekerjaan yang dulunya dikerjakan secara manual oleh manusia sekarang ini bisa digantikan oleh komputer. Seperti halnya dengan pencatatan kependudukan atau yang sering disebut sensus penduduk. Sensus penduduk adalah pencatatan total tentang penduduk dengan tujuan untuk mengetahui jumlah, komposisi, dan karakteristik penduduk yang dilaksanakan setiap sepuluh tahun sekali. Data sensus yang telah didapat akan disimpan dalam komputer dalam bentuk basis data yang dapat digunakan untuk keperluan-keperluan lain.

Wulunggunung adalah salah satu desa dari 15 desa yang berada di Kecamatan Sawangan, Kabupaten Magelang, Jawa Tengah. Desa Wulunggunung terletak di Lereng Gunung Merbabu dengan jumlah penduduk 2183 Jiwa Luas 330,103 Ha dengan ketinggian 1300 dpl. Dalam industri pertanian, desa Wulunggunung tersebut memiliki potensi yang sangat bagus seperti menanam sayur mayur dan tembakau. ${ }^{[3]}$

Dari hasil wawancara yang dilakukan pada saat kegiatan KKN bulan Agustus sampai September 2014, dapat disimpulkan bahwa Wulunggunung merupakan desa yang masih kurang dalam hal penggunaan teknologi dari desa-desa lain di Kecamatan Sawangan terutama dalam penggunaan komputer. Pencatatan penduduk di Balai Desa masih disimpan dalam Microsoft Excel dengan format penulisan yang masih kurang tertata dengan baik. Masalah muncul ketika terdapat warga yang pindah, datang, lahir ataupun meninggal. Perubahan data dilakukan secara manual sehingga akan sangat memakan waktu dalam proses perubahan data tersebut.

Maka dibangunlah aplikasi sensus penduduk ini yang diharapkan dapat membantu perangkat desa Wulunggunung dalam mengelola data penduduk, pembuatan laporan dan kepentingan-kepentingan lain. Selain itu akan tedapat suatu basis data yang valid pada Balai Desa tersebut agar tiap kepala dukuh/dusun disana dapat mencocokkannya data tersebut dengan warga yang tinggal pada dukuh/dusun tersebut sehingga jika ada suatu kesalahan maka pihak dari balai desa dapat mengubahnya di basis data tersebut.

Tugas akhir ini bertujuan untuk membuat suatu aplikasi yang dapat digunakan untuk pencatatan kependudukan dan keperluan lain di Balai Desa Wulunggunung.

Untuk menghindari pembahasan yang meluas, maka dalam tugas akhir ini ditetapkan batasan-batasan masalah sebagai berikut:

a. Yang di bahas pada tugas akhir ini meliputi tahap pembuatan aplikasi berbasis desktop.

b. Aplikasi dikembangkan dengan menggunakan bahasa Delphi.

c. Basis data dalam aplikasi ini hanya mencakup warga Desa Wulunggunung, Kecamatan Sawangan,Kabupaten Magelang.

\section{LANDASAN TEORI}

\section{A. Tinjauan Pustaka}

Penelitian tentang Sistem Informasi Jasa Pelayanan Kependudukan telah banyak dilakukan diantaranya adalah Kartika Sari pada Faisal ${ }^{[5]}$, mengemukakan tentang sistem informasi data kependudukan pada kecamatan Bulakamba Brebes. Aplikasi ini dapat membantu Kecamatan Bulakamba Brebes untuk memproses formulir-formulir tentang pengolahan data penduduk seperti formulir isian data kartu keluarga, formulir laporan kedatangan, formulir permohonan pindah, pengajuan Kartu Tanda Penduduk (KTP) dan formulir pelaporan kematian.

Nugraha pada Faisal ${ }^{[5]}$, mengemukakan tentang Perancangan Sistem Informasi Administrasi Kependudukan (SIAK) Sebagai Pengembangan E-Government menuju Good Governance. Aplikasi ini berfungsi untuk memberikan suatu kemudahan dalam segala proses yang berhubungan dengan kependudukan. Sistem ini dapat memberikan informasi yang cepat kepada masyarakat tentang pembuatan dokumen kependudukan, mempercepat dalam pembuatan dokumen 
kependudukan seperti pembuatan KTP, Kartu Keluarga(KK) dan surat lainnya, menyelenggarakan administrasi kependudukan yang benar, cepat dan akurat, mewujudkan pelayanan administrasi kependudukan dan catatansipil yang berorientasi kepada kepuasan dan kemitraan masyarakat menuju terciptanya data dan informasi kependudukan yang akurat.

Faisal, melakukan penelitian tentang Sistem Informasi Jasa Pelayanan Kependudukan pada Kelurahan Krapyak. Dalam aplikasi tersebut mempermudah proses dalam pendataan kependudukan yang dilakukan oleh para perangkat di Kelurahan Krapyak. Selain itu aplikasi tersebut dapat mencetak berbagai laporan yang diperlukan dalam kependudukan seperti laporan data kelahiran, kematian, kedatangan, kepindahan, data penduduk dan data pemohon KK. ${ }^{[5]}$

\section{B. Sistem Informasi}

Telah diketahui bahwa informasi merupakan hal yang sangat penting bagi manajemen di dalam pengambilan keputusan. Informasi dapat diperoleh dari sistem informasi, pengertian dari sistem informasi adalah : suatu sistem di dalam suatu organisasi yang mempertemukan kebutuhan pengolahan transaksi harian, mendukung informasi, bersifat manajerial dan kegiatan strategi dari suatu organisasi dan menyediakan pihak luar tertentu dengan laporan-laporan yang diperlukan.

Konsep dasar sistem didefinisikan menjadi dua pendekatan yaitu:

\section{Pendekatan Prosedur}

Sistem adalah suatu jaringan kerja dari sejumlah prosedur-prosedur yang saling berhubungan, berkumpul bersama-sama untuk melakukan suatu kegiatan atau untuk menyelesaikan suatu sasaran tertentu. ${ }^{[1]}$

\section{Pendekatan Elemen}

Sistem adalah elemen-elemen yang berinteraksi untuk mencapai suatu tujuan tertentu. ${ }^{[1]}$

Informasi adalah data yang diolah menjadi bentuk yang lebih berguna dan lebih berarti bagi penggunanya. Sumber informasi adalah data. Data merupakan bentuk jamak dari bentuk tunggal data item. Data adalah kenyataan yang menggambarkan suatu kejadian-kejadian dan kesatuan nyata.

Sistem informasi terdiri dari komponen-komponen yang disebut dengan istilah Blok Bangunan (building block). Yaitu blok masukan, blok model, blok keluaran, blok teknologi, blok basis data dan blok kendali. ${ }^{[1]}$

\section{a. Blok Masukan}

Input mewakili data yang masuk kedalam sistem informasi. Input disini termasuk metode dan media untuk menangkap data yang dimasukkan, yang dapat berupa dokumen-dokumen dasar. Data yang akan menjadi input dalam sistem sensus penduduk ini adalah data penduduk yang terdiri dari Nomor Induk Kependudukan(NIK),Nomor KK, nama lengkap, alamat,tempat lahir,tanggal lahir,jenis kelamin, agama, status hubungan dalam keluarga(SHDK), pendidikan terakhir, pekerjaan dan nama ibu.

\section{b. Blok Model}

Blok ini terdiri dari kombinasi prosedur, logika, dan model matematik yang akan dimanipulasi data input dan data yang disimpan dari basis data dengan cara tertentu untuk menghasilkan keluaran yang diinginkan. Dalam aplikasi sensus penduduk ini, data penduduk dapat dimanipulasi dengan berbagai perintah seperti perintah tambah,hapus dan edit.

\section{c. Blok Keluaran}

Produk dari sistem informasi adalah keluaran yang merupakan informasi yang berkualitas dan dokumentasi yang berguna untuk semua tingkatan manajemen serta semua pemakai sistem. Data yang sudah dimasukkan dalam aplikasi sensus penduduk tersebut langsung ditampilkan dalam bentuk tabel. Data pada tabel tersebut tidak bisa diubah langsung kecuali lewat prosedur yang sudah ditetapkan seperti prosedur tambah, hapus maupun edit.

\section{d. Blok Teknologi}

Blok teknologi merupakan tool box dalam sistem informasi. Teknologi digunakan untuk menerima input, menjalankan model penyimpanan dan mengakses data, menghasilkan dan mengirimkan keluaran dan membantu pengendalian dari sistem secara keseluruhan. Dalam aplikasi sensus penduduk ini teknologi yang digunakan berupa IDE Borland Delphi 7 yang digunakan sebagai compiler serta XAMPP sebagai server lokal untuk menyimpan basis data yang dalam aplikasi ini menggunakan basis data MySQL.

\section{e. Blok Basis Data}

Blok basis data merupakan kumpulan dari data yang saling berhubungan stau dengan yang lainnya. Dalam aplikasi sensus penduduk ini menggunakan basis data MySQL dalam penyimpanan data.

\section{f. Blok Kendali}

Banyak hal yang dapat merusak sistem informasi, seperti bencana alam, api, temperatur, air, debu, dan kegagalan-kegagalan sistem itu sendiri. Dalam aplikasi sensus penduduk ini perlu dilakukan cek berlaka pada komputer atau laptop yang dipasang aplikasi ini baik hardware maupun software.

Blok sistem informasi yang berinteraksi ditujukkan oleh Gambar 1 dibawah ini.

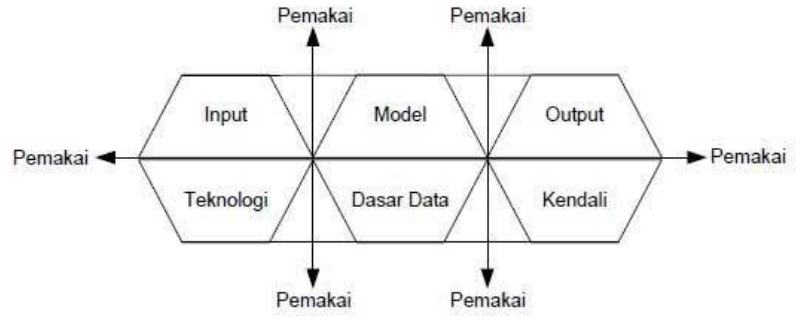

Gambar 1 Blok sistem informasi yang berinteraksi ${ }^{[1]}$

\section{Sensus Penduduk}

Sensus adalah prosedur sistematis memperoleh dan merekam / mencatat informasi tentang populasi tertentu. Sensus merupakan penghitungan secara teratur terjadi dan resmi dari populasi tertentu oleh pemerintah. Istilah ini digunakan terutama dalam kaitannya dengan populasi nasional dan sensus perumahan. Sensus umum lainnya mencakup pertanian, bisnis, dan sensus lalu lintas . Dalam kasus yang terakhir unsur-unsur dari penduduk adalah peternakan, bisnis, dan sebagainya, ketimbang orang. PBB mendefinisikan fitur penting dari sensus penduduk dan perumahan yaitu pencacahan individu, universalitas dalam wilayah tertentu. ${ }^{[4]}$

Sensus dapat dibandingkan dengan pengambilan sampel di mana informasi diperoleh hanya dari subset dari populasi, kadang-kadang sebagai estimasi antar data sensus umumnya digunakan untuk penelitian, pemasaran bisnis, dan 
perencanaan, serta sebagai dasar untuk survei sampling. Di beberapa negara, data sensus yang digunakan untuk membagi representasi pemilihan. ${ }^{[4]}$

Data sensus yang dikumpulkan meliputi karakteristik demografi, ketenagakerjaan, dan sosial budaya. Karakteristik demografi yang dikumpulkan adalah mengenai kelahiran, kematian,pindah dan datang. Data yang dihimpun pada bidang ketenagakerjaan mencakup lapangan usaha, jenis pekerjaan, dan status pekerjaan. Sedangkan data sosial budaya mencakup tingkat pendidikan, kondisi tempat tinggal, dan kegiatan penduduk lanjut usia (lansia).

Data-data dari sensus tersebut digunakan untuk perencanaan pembangunan di berbagai bidang. Hal tersebut sangat berperan penting untuk mengetahui tingkat keberhasilan pembangunan, baik di bidang kependudukan, sosial budaya, dan ketenagakerjaan. Selain itu data-data tersebut dapat digunakan acuan dalam pembuatan suatu surat seperti surat keterangan pengantar dan surat pindah.

\section{Delphi}

Delphi adalah kompiler / penterjemah bahasa Delphi (awalnya dari Pascal) yang merupakan bahasa tingkat tinggi sekelas dengan bahasa pemrograman Basic, C. Bahasa Pemrograman di Delphi disebut bahasa prosedural artinya bahasa/sintaknya mengikuti urutan tertentu / prosedur. Ada jenis pemrograman non-prosedural seperti pemrograman untuk kecerdasan buatan contohnya bahasa Prolog. Delphi termasuk Keluarga Pemrograman Visual sekelas dengan Visual Basic, Visual C, artinya perintah-perintah untuk membuat objek dapat dilakukan secara visual. Pemrogram tinggal memilih objek apa yang ingin dimasukkan kedalam Form/Window, lalu tingkah laku objek tersebut saat menerima event/aksi tinggal dibuat programnya. Delphi juga merupakan bahasa pemrograman berorentasi objek, artinya nama objek, properti dan methodelprocedure dikemas menjadi satu kemasan (encapsulate).

Sebelum kita mempelajari pemrograman menggunakan Delphi ada baiknya kita mengenali dahulu tampilan IDE, yang merupakan editor dan tools untuk membuat program Delphi. Pada IDE akan ditampilkan form baru yang merupakan aplikasi/program Window yang akan kita buat. Delphi adalah sebuah perangkat lunak (bahasa pemrograman) untuk membuat program / aplikasi komputer yang berbasis windows (VCL) dan berbasis Linux $(C L X)$.

\section{E. $M y S Q L$}

MySQL adalah salah satu jenis database server yang sangat terkenal. MySQL termasuk jenis Relational Database Management System (RDBMS) yang di desain untuk system dengan arsitektur klien/server. ${ }^{[2]}$

Kepopulerannya disebabkan MySQL menggunakan SQL sebagai bahasa dasar untuk mengakses database yang terbagi menjadi tiga bagian, yaitu DDL, DML dan DCL. Selain itu, MySQL bersifat free (tidak perlu membayar untuk menggunakannya).

1. Data Definition Language (DDL) merupakan kelompok perintah yang berfungsi untuk mendefinisikan atributatribut basis data, tabel, atribut (kolom), batasan-batasan terhadap suatu atribut, serta hubungan antar tabel.

2. Data Manipulation Language (DML) adalah kelompok perintah yang berfungsi untuk memanipulasi data dalam database, misalnya untuk pengambilan, penyisipan, pengubahan, dan penghapusan data.

3. Data Control Language (DCL) berisi perintah-perintah untuk mengendailkan pengaksesan data. Pengendalian dapat dilakukan berdasarkan pengguna, tabel, kolom maupun operasi yang boleh dilakukan.

\section{PERANCANGAN Sistem}

\section{A. Kondisi Awal}

Dari wawancara dan pengamatan yang dilakukan selama dilakukan KKN di Desa Wulunggunung didapatkan gambaran kondisi dilapangan. Berikut merupakan beberapa kondisi dilapangan:

1. Pencatatan penduduk menggunakan aplikasi Microsoft Excel.

2. Laporan Sensus disajikan dalam Microsoft Excel secara ketik manual.

3. Pengisian Surat Keterangan Pengantar dan Surat Pindah masih manual (pembuat surat mengisi formulir sendiri).

\section{Kebutuhan Fungsional}

Kebutuhan fungsional merupakan kebutuhan yang meliputi fungsi yang ada pada aplikasi dan berkaitan langsung dengan fitur - fitur pada aplikasi. Kebutuhan Fungsional dari aplikasi Sensus Penduduk ini adalah sebagai berikut:

1. Pengguna yang akan mengoperasikan aplikasi ini yaitu Perangkat Desa yang bertugas sebagai Administrator.

2. Fungsi admin dalam mengelola data penduduk yaitu menambah ,mengedit, menghapus data penduduk

3. Fungsi admin dalam mengelola data kejadian yaitu menambah ,mengedit, menghapus data kejadian

4. Fungsi admin dalam pembuatan surat pindah dan surat keterangan pengantar

5. Fungsi admin dalam pembuatan laporan data kejadian pertahun

\section{Kebutuhan Non-Fungsional}

Kebutuhan non fungsional tidak berkaitan langsung dengan fitur-fitur pada aplikasi namun kebutuhan ini akan memberikan batasan kepada kebutuhan fungsional. Berikut merupakan kebutuhan non fungsional aplikasi Sensus Penduduk:

1. Operasional : Dapat diakses melalui perangkat komputer

2. Keamanan : Penggunaan Login untuk bisa masuk ke dalam sistem

Sistem yang dikembangkan berupa aplikasi berbasis desktop dengan menggunakan server local di komputer. Data yang diolah sistem disimpan pada basis data. Dalam menjalankan aplikasi ini komputer harus memiliki spesifikasi perangkat keras dan perangkat lunak yang memadai untuk menjalankan aplikasi ini. Berikut merupakan kebutuhan minimal untuk sistem ini:

1. Perangkat Keras
a. Processor : Intel Dual Core
b. RAM : $256 \mathrm{MB}$ atau diatasnya
c. HDD : $50 \mathrm{~GB}$

2. Perangkat Lunak

\section{a. Windows 7}

b. XAMPP-PORTABLE 1.8.1

c. Web Browser (untuk mengakses basis data di XAMPP)

\section{B. Pemodelan Diagram Alir}

Pada tahap ini bertujuan untuk menjelaskan segala sesuatu yang akan ditangani oleh perangkat lunak. Analisis ini akan menjabarkan mengenai sifat dari perangkat lunak yang akan dibangun. Pada diagram ini menggambarkan secara detail atau secara rinci tentang proses atau urutan logika yang terjadi dalam sebuah program Diagram alir sistem ditunjukkan oleh Gambar 2 berikut. 


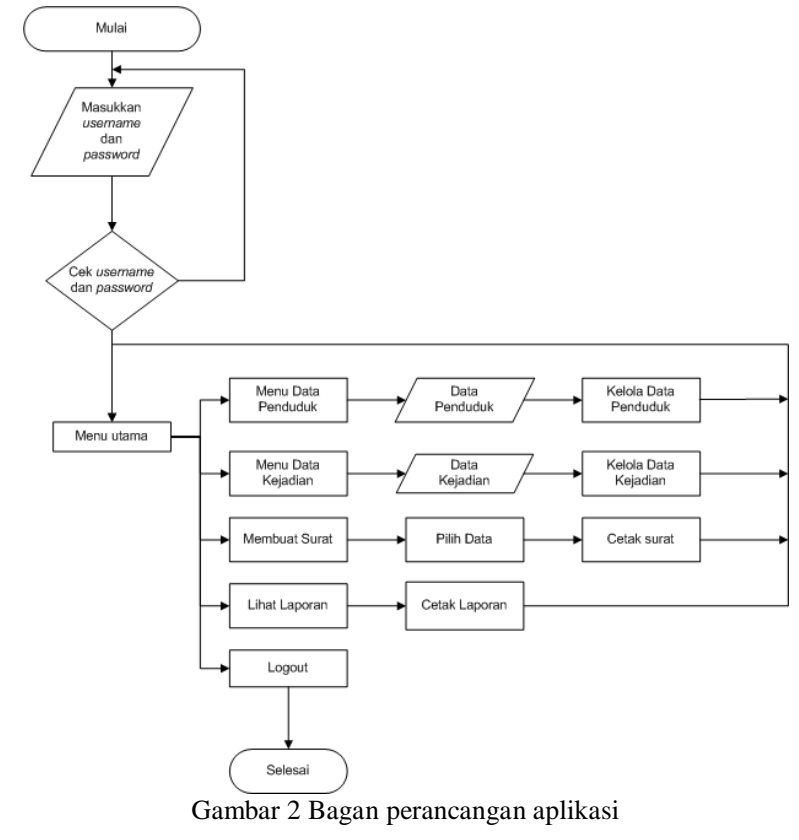

\section{Diagram Dekomposisi}

Dekomposisi diagram adalah alat yang digunakan untuk menggambarkan dekomposisi system. disebut juga bagan hierarki, menunjukkan dekomposisi fungsional top-down dan struktur sistem. Diagram dekomposisi ini dibuat sebagai acuan dalam pembuatan diagram alir data(DFD). Diagram dekomposisi aplikasi sensus penduduk ditunjukkan oleh Gambar 3 berikut ini.

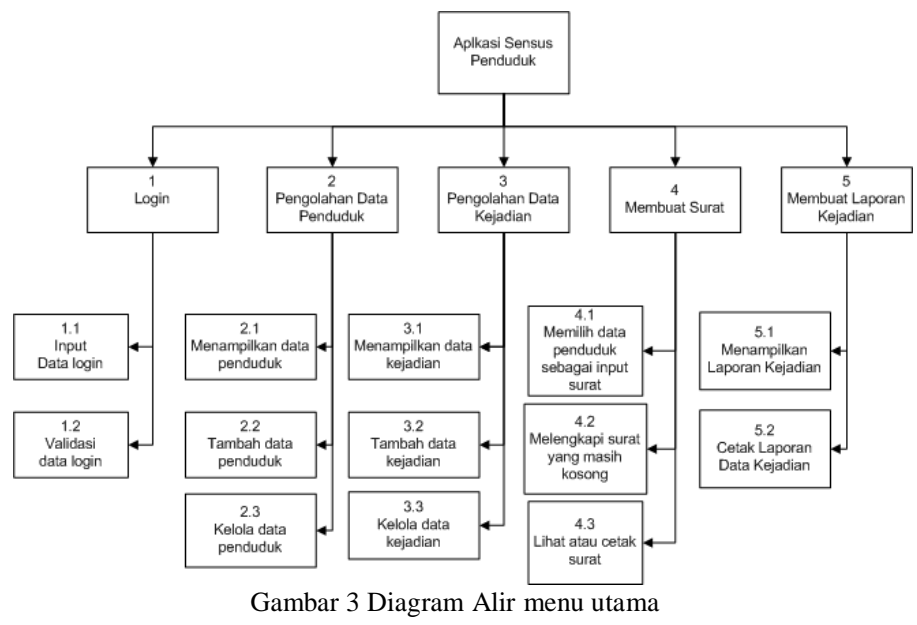

\section{D.Data Flow Diagram}

DFD (Data Flow Diagram) digunakan untuk menggambarkan suatu sistem yang telah ada atau sistem yang akan dikembangkan secara logika tanpa mempertimbangkan lingkungan fisik yang dihubungkan satu sama lain dengan alur data, baik secara manual maupun komputerisasi.

1. DFD level 0

DFD level 0 atau bisa juga disebut Diagram Context yaitu gambaran dasar dari sistem yang akan dibuat dan akan didekomposisikan lebih detail pada DFD level selanjutnya. Gambar 4akan menjelaskan aliran data pada DFD level 0.

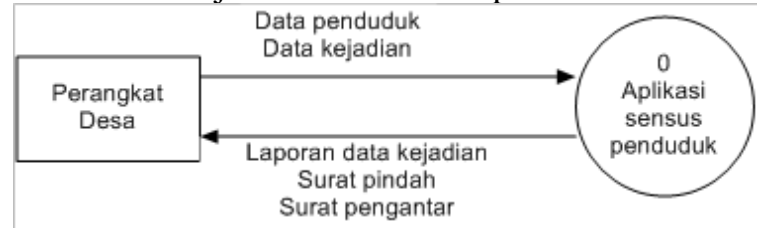

Gambar 4Diagram Context aplikasi sensus penduduk
Pada DFD level 0 pelaku yang menggunakan sistem ini hanya satu yaitu perangkat desa. Segala kegiatan yang dilakukan dengan oleh aplikasi ini hanya diakses oleh perangkat desa tanpa ada hak akses apapun.

\section{DFD level 1}

Pada DFD level 1 ini merupakan penjabaran dari diagram konteks aplikasi sensus penduduk ini. Pada DFD level 1 initerdapat beberapa fungsi yang ada pada aplikasi sensus penduduk beserta aliran datanya. DFD level 1 aplikasi sensus penduduk ditunjukkan pada gambar 5 berikut.

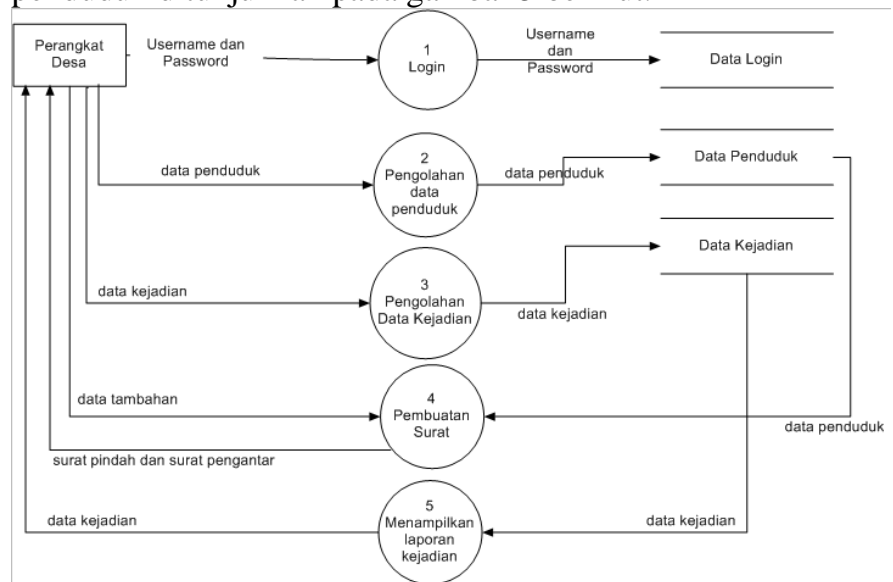

a. Login

Gambar 5DFD level 1 aplikasi sensus penduduk

Proses ini merupakan tampilan awal dalam aplikasi sebelum masuk ke dalam menu utama aplikasi di sistem ini. Pengguna tidak dapat masuk kedalam menu utama sistem tanpa melalui proses login ini.

b. Mengelola data penduduk

Proses ini merupakan sistem pengelolaan data penduduk dalam aplikasi ini. Proses ini berisi menambah data penduduk, edit data penduduk, hapus data penduduk serta menampilkan data penduduk.

c. Mengelola data kejadian

Proses ini merupakan sistem pengelolaan data kejadian dalam aplikasi ini. Proses ini berisi menambah data kejadian, edit data kejadian, hapus data kejadian serta menampilkan data kejadian.

d. Pembuatan surat

Proses ini merupakan proses untuk membuat surat pindah dan surat keterangan.

e. Membuat laporan kejadian

Proses ini adalah proses membuat laporan suatu kejadian selama setahun yang tersimpan pada data kejadian. Laporan kejadian yang disajikan dapat langsung dicetak maupun diubah formatnya menjadi excel.

3. DFD level 2 (login)

Sebelum masuk ke aplikasi terlebih dahulu melalui proses login ini. Pengguna memasukkan username dan password pada form login. Sistem akan mengecek apakah username dan password yang telah dimasukkan sesuai dengan yang tersimpan di basis data. Jika tidak, maka ada peringatan username dan password salah. Jika sesuai maka ada peringatan username dan password cocok kemudian akan masuk ke dalam menu utama sistem. DFD level 2 pada fungsi login ditunjukkan oleh Gambar 6 berikut. 


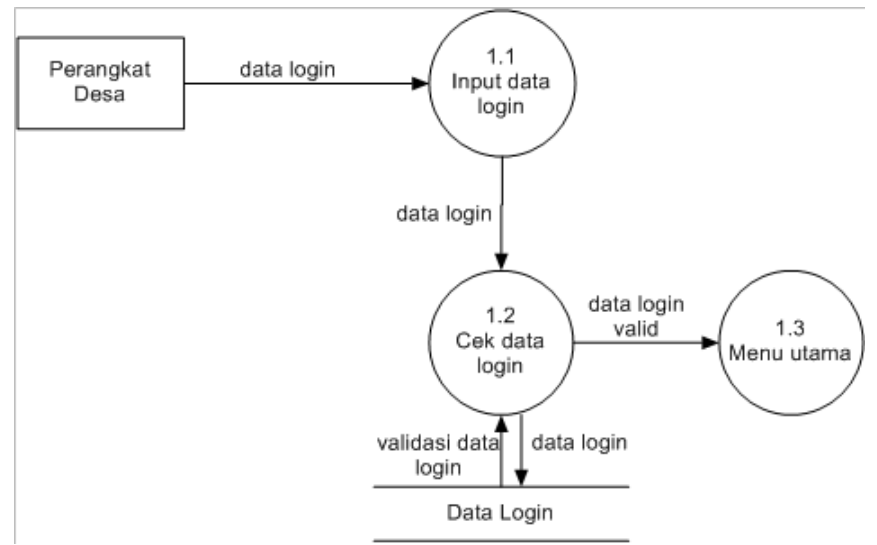

Gambar 6 DFD level 2 pada fungsi lo

4. DFD level 2 (mengelola data penduduk)

Proses ini merupakan proses untuk mengelola data penduduk. Untuk menambahkan data penduduk, pengguna mengisi form tambah penduduk kemudian akan di simpan pada basis data. Jika ingin mengelola data panduduk seperti mengedit ataupun menghapus, data yang akan di edit atau di hapus dipilih pada basis data kemudian dieksekusi sesuai dengan perintah. Setelah di edit maupun di hapus maka pada basis data aka nada perbaharuan secara otomatis.DFD level 2 pada fungsi kelola data penduduk ditunjukkan oleh gambar 7 berikut.

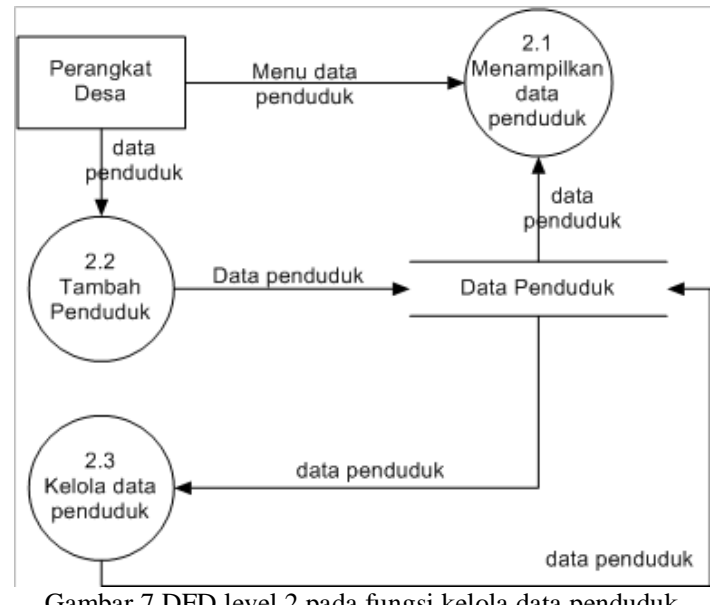

5. DFD level 2 (mengelola data kejadian)

Proses ini mengelola data kejadian seperti menambah data kejadian, mengedit maupun menghapus data kejadian. Data yang sudah dikelola akan ditampilkan pada menu data kejadian. DFD level 2 pada fungsi kelola data kejadian ditunjukkan oleh gambar 8 berikut.

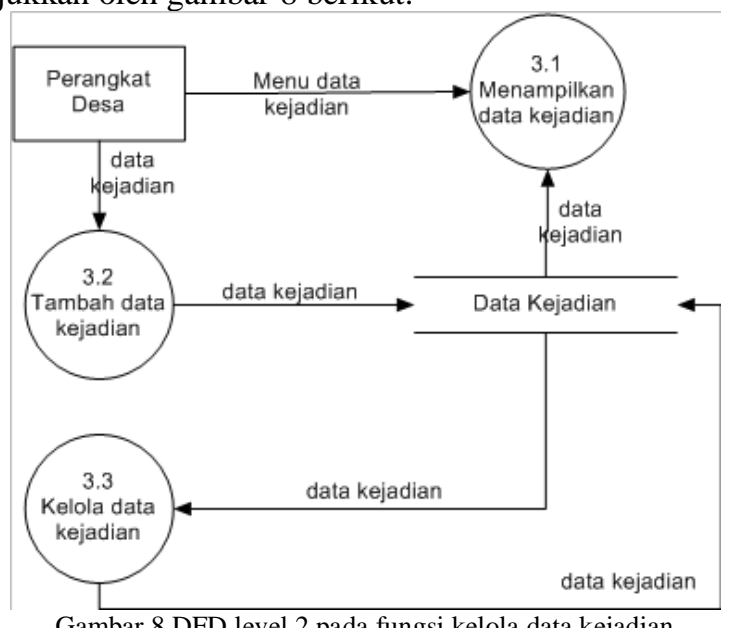

6. DFD level 2 (mengelola pembuatan surat)

Sebelum membuat surat, pengguna memilih salah satu dari data penduduk yang tersedia untuk mengisi form pada surat. Kemudian pengguna mengisi data di form surat yang masih kosong ataupun harus diisi manual seperti alasan ,keterangan lain dan lain sebagainya.DFD level 2 pada fungsi membuat surat ditunjukkan oleh gambar 9 berikut.

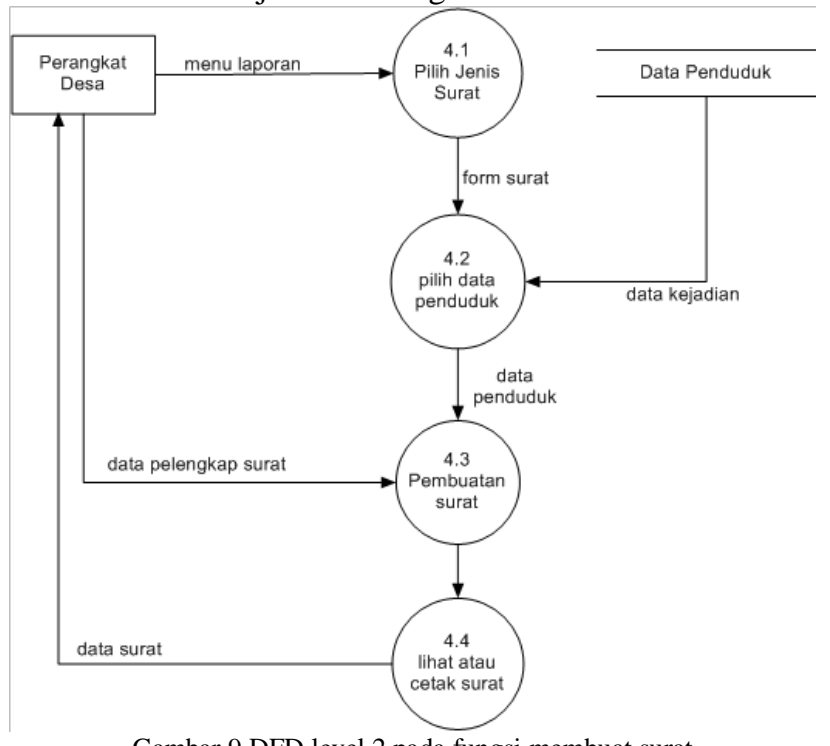

7. DFD level 2 (kelola laporan data kejadian)

Proses ini mencetak laporan yang digunakan oleh pengguna untuk kebutuhan arsip . Laporan yang di cetak yaitu data kejadian sesuai dengan tahun yang telah dipilih.DFD level 2 pada fungsi cetak laporan ditunjukkan oleh gambar 10 berikut.

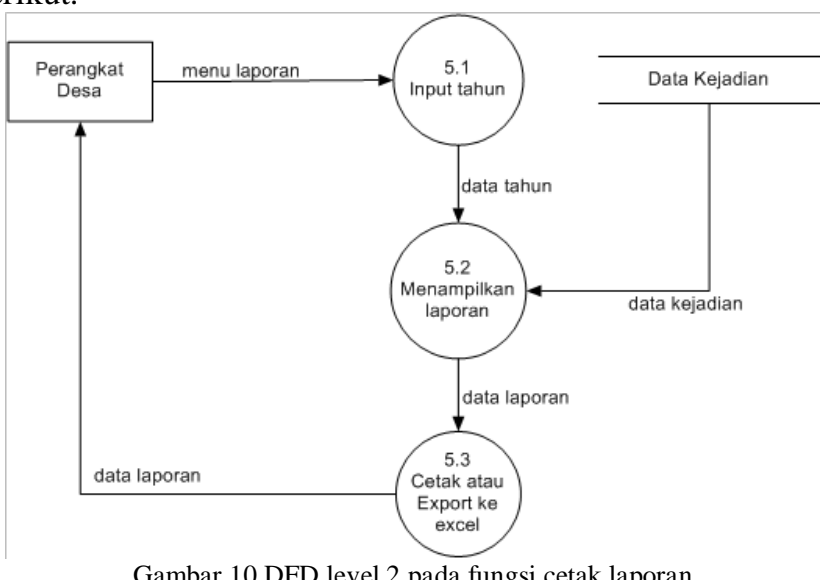

\section{E. Perancangan Basis Data}

Basis data yang digunakan aplikasi Sensus Penduduk ini adalah MySQL. Perancangan basis data ini akan dilakukan dengan bantuan ERD ( Entity Relationship Diagram). Dan juga akan terjadi relasi antar tabel dalam basis data yang dibuat.

1. Menentukan Entitas

Pada aplikasi sensus penduduk ini akan ditentukan beberapa entitas yang akan dimasukkan dalam perancangan basis data ini yang ditunjukkan oleh tabel 1 berikut ini.

Tabel 1 Entitas yang digunakan pada aplikasi sensus penduduk

\begin{tabular}{|l|l|l|}
\hline No & Nama Entitas & Keterangan \\
\hline 1. & data_Penduduk & $\begin{array}{l}\text { Data Penduduk Desa } \\
\text { Wulunggunung }\end{array}$ \\
\hline 2. & data_Pertambahan & $\begin{array}{l}\text { Data Pertambahan Kejadian di } \\
\text { Desa Wulunggunung }\end{array}$ \\
\hline
\end{tabular}




\begin{tabular}{|l|l|l|}
\hline 3. & data_kejadian & $\begin{array}{l}\text { Data Perkembangan Kejadian } \\
\text { tiap dusun }\end{array}$ \\
\hline 4. & data_kejadian_2 & Data Perkembangan Penduduk \\
\hline 5. & data_kejadian_3 & $\begin{array}{l}\text { Data perkembanga berdasarkan } \\
\text { umur }\end{array}$ \\
\hline
\end{tabular}

2. Relasi antar entitas

Diagram relasi entitas dapat digambarkan setelah seluruh entitias didefinisikan beserta atributnya. Tujuan dari diagram adalah menjelaskan hubungan antara entitas yang telah ditentukan. Relasi yang digambarkan dapat diperjelas dengan menambahkan informasi kardinalitas antara entitas. Berikut merupakan relasi pada aplikasi sensus penduduk yang ditujukan oleh gambar 11 berikut ini.

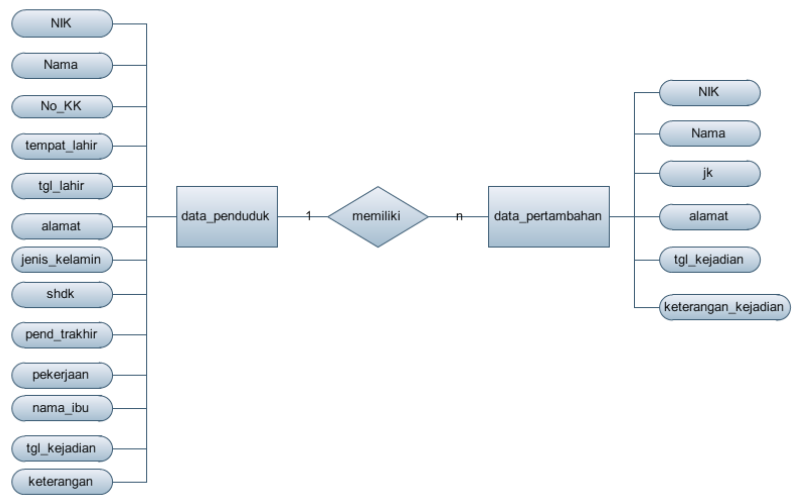

3. Perancangan antarmuka

Dalam pengembangan antarmuka aplikasi ini menggunakan Alphaskin agar antarmuka yang dimunculkan terlihat lebih bagus. Ada beberapa tampilan yang disediakan oleh Alphaskin agar pengguna dapat memilih yang paling sesuai dengan apa yang diinginkan.

Dalam pengembangan aplikasi ini terdapat beberapa antarmuka yang akan digunakan yaitu:

1. Formlogin

Antarmuka login akan digunakan agar pengguna dapat masuk ke dalam sistem. Formlogin ditunjukkan pada Gambar 12 berikut ini.

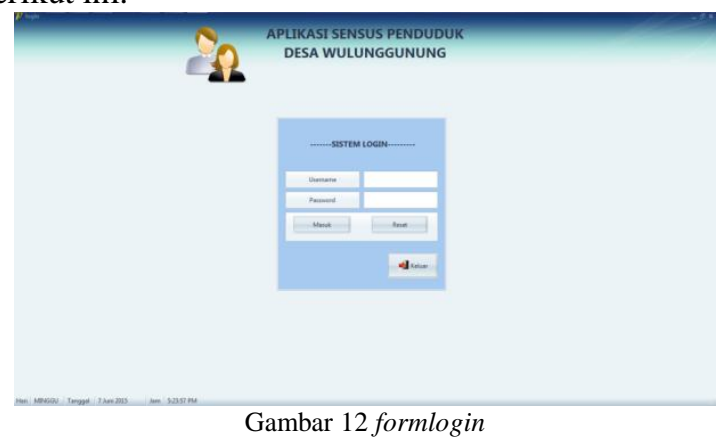

2. Form menu utama

Antarmuka menu utama akan muncul jika pengguna sukses dalam melakukan login. Form menu utama ditunjukkan pada gambar 13 berikut ini.

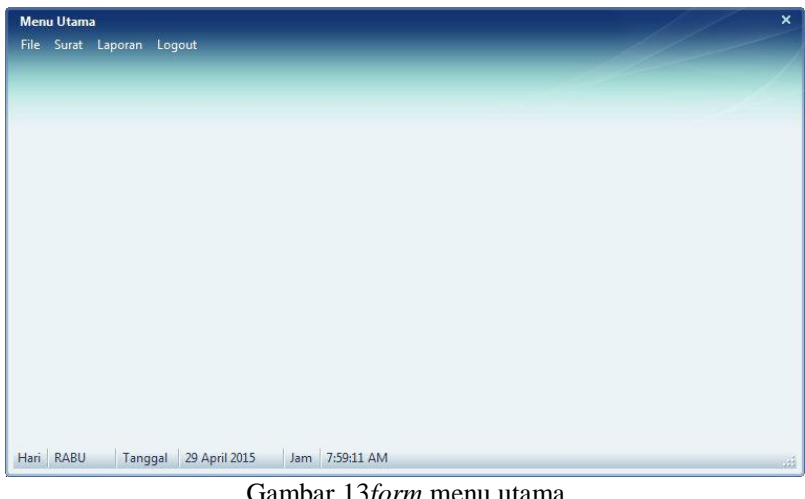

3. Form tampilan data penduduk

Antarmuka ini akan muncul jika submenu Data Penduduk di tekan. Antarmuka ini berisi tampilan data penduduk secara lengkap. Selain itu ada juga beberapa perintah seperti tambah, edit, hapus, dan cari. Form tampilan data penduduk ditunjukkan pada Gambar 14 berikut ini.

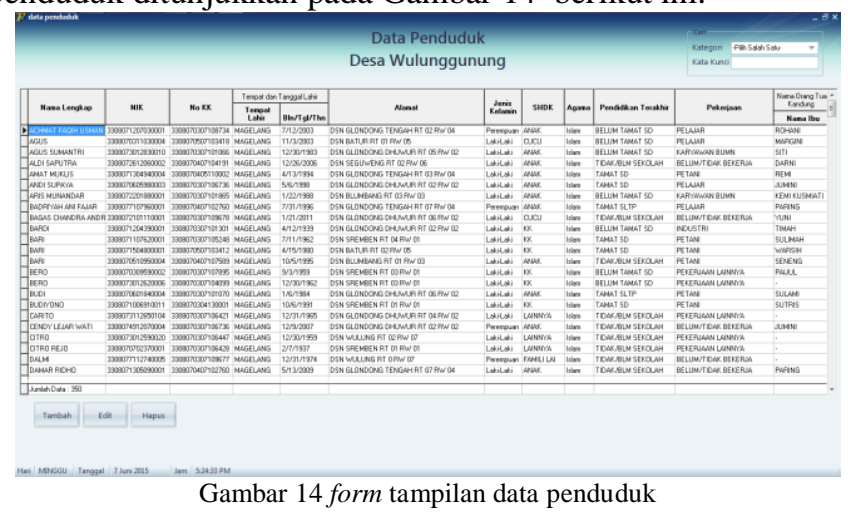

4. Form tambah/edit data penduduk

Antarmuka ini akan muncul jika perintah tambah atau edit di tekan pada antarmuka tampilan penduduk. Form tambah/edit data penduduk ditunjukkan pada Gambar 15 berikut ini.

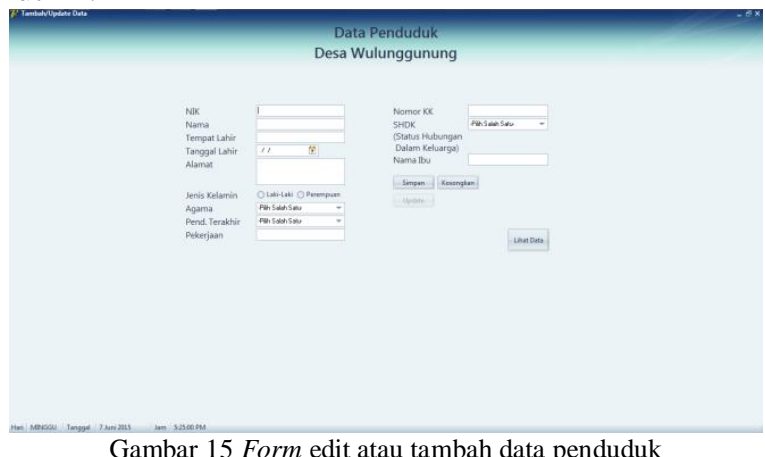

5. Form kelola data kejadian

Antarmuka kelola data kejadian ini berisi tampilan data kejadian beserta perintah manipulasi seperti tambah, edit dan hapus. Form kelola data kejadian ditunjukkan pada Gambar 16 berikut ini.

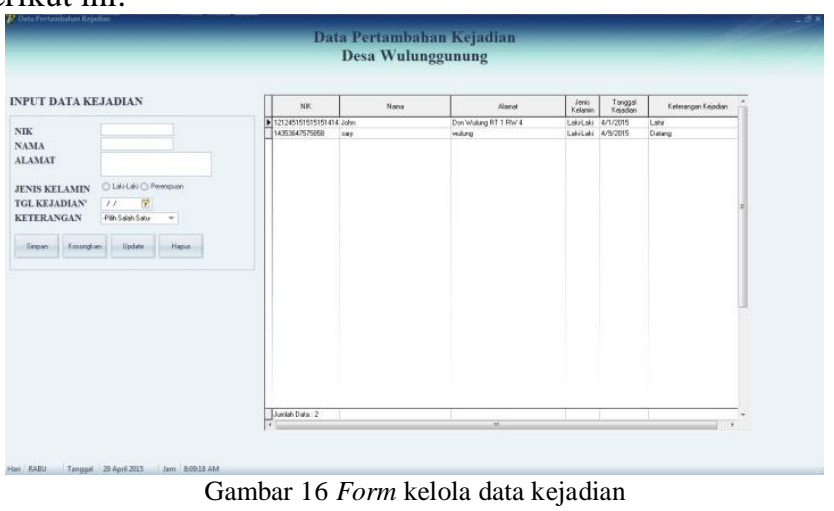




\section{Formsurat pindah}

Antarmuka surat pindah ini menampilkan elemen apa saja yang dibutuhkan untuk membuat sebuah surat pindah. Sebelum itu harus memilih data penduduk yang akan mambuat surat pindah ini. Formsurat pindah ditunjukkan pada Gambar 17 berikut ini.

7. Formsurat keterangan

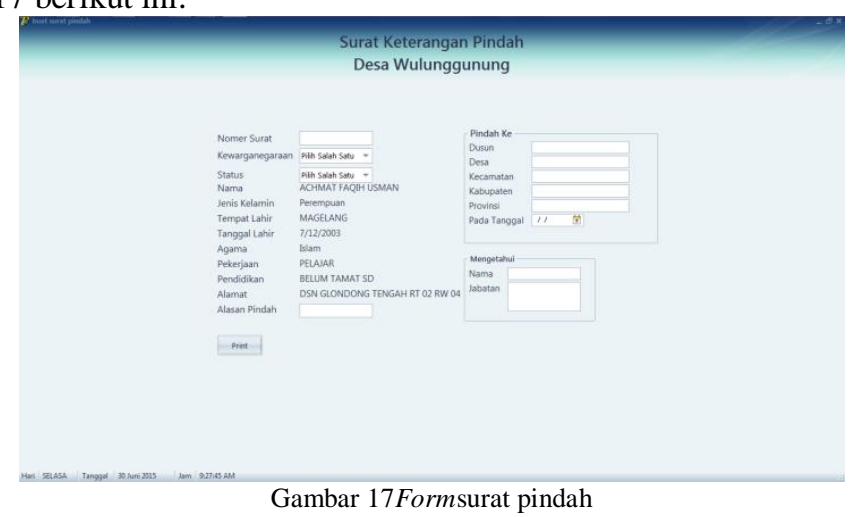

Antarmuka surat keterangan ini menampilkan elemen apa saja yang dibutuhkan untuk membuat sebuah surat pindah. Sebelum itu harus memilih data penduduk yang akan mambuat surat pindah ini. Formsurat keterangan ditunjukkan pada Gambar 18 berikut ini.

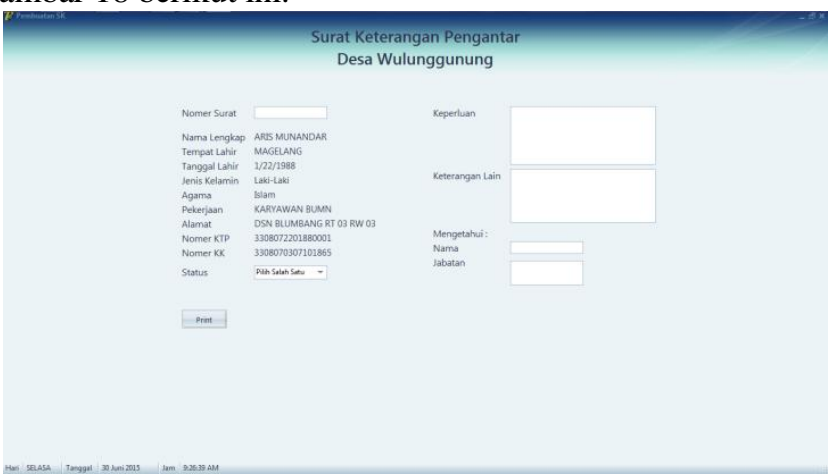

Gambar 18Formsurat keterangan

8. Form tabel laporan

Antarmuka ini menampilkan laporan data kejadian yang tersimpan pada basis data. Form tabel laporan ditunjukkan pada Gambar 19 berikut ini.

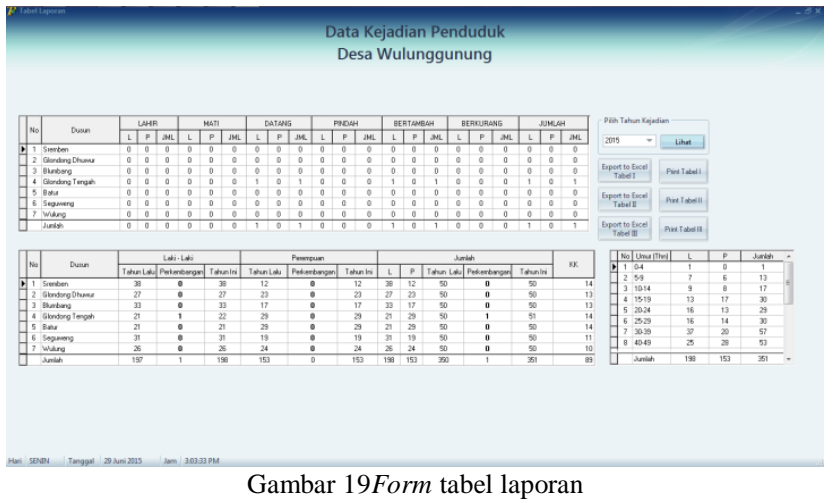

\section{PEMBAHASAN}

\section{A. Pengujian Unit}

Pengujian unit dilakukan dalam pengujian aplikasi sensus penduduk ini. Pengujian unit adalah melakukan analisis dari masing masing fungsi didalam suatu sistem. Tujuan pengujian unit adalah membatasi objek pengujian dalam skala kecil sehingga tahap perbaikan akan lebih cepat jika ditemukan kesalahan. Pengujian unit dilakukan dengan menjalankan setiap fungsi didalam sistem. Metode pengujian yang digunakan dalam pengujian unit ini adalah teknik kotak hitam (black box). Metode tersebut adalah untuk memastikan masingmasing fungsi pada sistem berjalan dengan cara diamati ketika fungsi dieksekusi.

Berikut merupakan daftar pengujian beserta analisis secara lengkap yang ditunjukkan pada tabel 2 berikut.

Tabel 2 Pengujian Unit

\begin{tabular}{|c|c|c|c|}
\hline Pengujian & Tindakan & $\begin{array}{l}\text { Hasil yang } \\
\text { diharapkan }\end{array}$ & Analisis \\
\hline $\operatorname{login}$ & $\begin{array}{l}\quad \text { memasukkan } \\
\text { username dan } \\
\text { password pada } \\
\text { formlogin } \\
\text { kemudian } \\
\text { menekan } \\
\text { tombol masuk }\end{array}$ & \begin{tabular}{l}
\multicolumn{1}{c}{ terdapat } \\
konfirmasi \\
bahwa login \\
berhasil, \\
kemudian \\
form menu \\
utama akan \\
muncul
\end{tabular} & Berhasil \\
\hline $\begin{array}{l}\text { melihat data } \\
\text { penduduk }\end{array}$ & \begin{tabular}{l}
\multicolumn{1}{c}{ memilih } \\
menu file>data \\
penduduk \\
pada menu \\
utama
\end{tabular} & $\begin{array}{l}\text { muncul } \\
\text { form data } \\
\text { penduduk } \\
\text { yang berisi } \\
\text { data } \\
\text { penduduk }\end{array}$ & berhasil \\
\hline $\begin{array}{c}\text { menambah } \\
\text { data penduduk }\end{array}$ & $\begin{array}{l}\text { mengisi data } \\
\text { pada form } \\
\text { tambah/edit } \\
\text { data penduduk }\end{array}$ & $\begin{array}{l}\text { data dapat } \\
\text { tersimpan } \\
\text { dalam basis } \\
\text { data }\end{array}$ & berhasil \\
\hline $\begin{array}{c}\text { mengedit } \\
\text { data penduduk }\end{array}$ & \begin{tabular}{l}
\multicolumn{1}{c}{ mengedit } \\
data yang \\
sudah dipilih \\
pada form \\
tambah/edit \\
data penduduk
\end{tabular} & \begin{tabular}{l}
\multicolumn{1}{c}{ data yang } \\
sudah diedit \\
tersimpan \\
dalam basis \\
data
\end{tabular} & berhasil \\
\hline $\begin{array}{c}\text { menghapus } \\
\text { data penduduk }\end{array}$ & $\begin{array}{l}\text { memilih data } \\
\text { pendudukm } \\
\text { kemudian } \\
\text { menekan } \\
\text { tombol hapus }\end{array}$ & \begin{tabular}{l}
\multicolumn{1}{c}{ data yang } \\
dipilih dapat \\
terhapus dari \\
sistem
\end{tabular} & berhasil \\
\hline $\begin{array}{l}\text { melihat data } \\
\text { kejadian }\end{array}$ & \begin{tabular}{l}
\multicolumn{1}{c}{ memilih } \\
menu file>data \\
kejadian pada \\
menu utama
\end{tabular} & \begin{tabular}{l}
\multicolumn{1}{c}{ masuk ke } \\
form \\
pertambahan \\
dan tabel \\
yang berisi \\
data kejadian \\
akan tampil.
\end{tabular} & berhasil \\
\hline $\begin{array}{c}\text { menambah } \\
\text { data kejadian }\end{array}$ & $\begin{array}{l}\text { mengisi form } \\
\text { input data } \\
\text { kejadian }\end{array}$ & $\begin{array}{l}\text { data akan } \\
\text { tersimpan } \\
\text { dan terlihat } \\
\text { di tabel } \\
\text { kejadian } \\
\end{array}$ & berhasil \\
\hline $\begin{array}{c}\text { mengedit } \\
\text { data kejadian }\end{array}$ & $\begin{array}{l}\text { memilih data } \\
\text { yang akan } \\
\text { diedit, } \\
\text { kemudian } \\
\text { mengubahnya } \\
\text { pada form } \\
\text { input data } \\
\text { kejadian dan } \\
\text { menekan } \\
\text { tombol update. }\end{array}$ & $\begin{array}{l}\text { data yang } \\
\text { diedit akan } \\
\text { tersimpan } \\
\text { dan terlihar } \\
\text { di tabel } \\
\text { kejadian }\end{array}$ & berhasil \\
\hline $\begin{array}{r}\text { menghapus } \\
\text { data kejadian }\end{array}$ & \begin{tabular}{l}
\multicolumn{1}{c}{ memillih } \\
data yang akan \\
dihapus \\
kemudian \\
menekan \\
tombol hapus.
\end{tabular} & \begin{tabular}{l}
\multicolumn{1}{c}{ data } \\
dihapus \\
dalam basis \\
data.
\end{tabular} & berhasil \\
\hline
\end{tabular}




\begin{tabular}{|c|c|c|c|}
\hline \begin{tabular}{l}
\multicolumn{1}{c}{ membuat } \\
surat \\
keterangan \\
pengantar
\end{tabular} & $\begin{array}{l}\text { memilih data } \\
\text { penduduk dan } \\
\text { mengisi form } \\
\text { surat } \\
\text { keterangan } \\
\text { pengantar } \\
\text { kemudian } \\
\text { menekan } \\
\text { tombol } \\
\text { preview }\end{array}$ & \begin{tabular}{l}
\multicolumn{1}{c}{ surat } \\
pengantar \\
berhasil \\
dibuat dan \\
siap untuk \\
dicetak.
\end{tabular} & berhasil \\
\hline \begin{tabular}{l}
\multicolumn{1}{c}{ membuat } \\
surat \\
keterangan \\
pindah
\end{tabular} & $\begin{array}{l}\text { memilih data } \\
\text { penduduk, } \\
\text { mengisi form } \\
\text { surat pindah } \\
\text { dan menekan } \\
\text { tombol } \\
\text { preview. }\end{array}$ & \begin{tabular}{l}
\multicolumn{1}{c}{ surat } \\
pindah \\
berhasil \\
dibuat dan \\
sial untuk \\
dicetak
\end{tabular} & berhasil \\
\hline $\begin{array}{l}\text { melihat } \\
\text { laporan } \\
\text { kejadian } \\
\text { pertahun }\end{array}$ & \begin{tabular}{l}
\multicolumn{1}{c}{ memilih } \\
tahun, \\
kemudian \\
menekan \\
tombol lihat
\end{tabular} & \begin{tabular}{l}
\multicolumn{1}{c}{ tabel yang } \\
tersaji akan \\
menampilkan \\
data kejadian \\
sesuai \\
dengan tahun \\
yang dipilih.
\end{tabular} & berhasil \\
\hline $\begin{array}{l}\text { mengkonver } \\
\text { si tabel ke } \\
\text { dalam excel }\end{array}$ & \begin{tabular}{l}
\multicolumn{1}{c}{ menekan } \\
tombol export \\
tabel $1 / 2 / 3 \mathrm{ke}$ \\
dalam bentuk \\
excel
\end{tabular} & $\begin{array}{l}\text { data akan } \\
\text { dipindah } \\
\text { kedalam } \\
\text { bentuk excel } \\
\text { dan akan } \\
\text { ditampilkan }\end{array}$ & berhasil \\
\hline $\begin{array}{l}\text { mencetak } \\
\text { laporan data } \\
\text { kejadian }\end{array}$ & \begin{tabular}{l}
\multicolumn{1}{c}{ menekan } \\
tombol print \\
sesuai tabel \\
yang \\
diinginkan
\end{tabular} & \begin{tabular}{l}
\multicolumn{1}{c}{ laporan } \\
akan muncul \\
dan siap \\
dicetak
\end{tabular} & berhasil \\
\hline
\end{tabular}

\section{B. Pengujian Integrasi}

Pengujian integrasi dilakukan untuk mengetahui apakah setiap fungsi yang ada didalam sistem mampu saling terhubung untuk melakukan pekerjaan utama. Pengujian dilakukan karena kesalahan dalam sistem mungkin terjadi walaupun masing-masing fungsi telah berhasil diuji satu persatu. Kesalahan seperti itu umumnya terjadi karena fungsi yang ada tidak terhubung atau tidak memiliki batasan yang sama dengan fungsi lainnya.

Dalam penerapan dilapangan, petugas dibalai desa mengeksekusi banyak fungsi dalam melakukan pekerjaannya. Hubungan antar fungsi tersebut adalah bentuk integrasi unit. Skenario buatan atau simulasi pekerjaan petugas dilakukan untuk menjalankan pengujian integrasi agar aplikasi dapat berjalan dengan baik.Berikut merupakan hasil analisa dari pengujian integrasi tersebut ditunjukkan oleh tabel 3 berikut.

Tabel 3 Analisa pengujian integrasi

\begin{tabular}{|c|c|c|c|}
\hline Skenario & Fungsi yang terkait & Analisa & stikubank, \\
\hline $\begin{array}{l}\text { Membuat surat } \\
\text { keterangan } \\
\text { pengantar }\end{array}$ & $\begin{array}{l}\text { login, memilih data } \\
\text { penduduk,mengisi } \\
\text { yang belum terisi, mencetak } \\
\text { surat keterangan }\end{array}$ & Berhasil & $\begin{array}{l}\text { [5] Yusrizal } \\
\text { NEGARA } \\
\text { Aceh,2012. }\end{array}$ \\
\hline $\begin{array}{l}\text { Menambah data } \\
\text { kejadian baru } \\
\text { menggunakan data } \\
\text { penduduk baru }\end{array}$ & $\begin{array}{l}\text { login, menambah data } \\
\text { penduduk, menambah data } \\
\text { kejadian }\end{array}$ & Berhasil & \\
\hline $\begin{array}{lr}\text { Mencetak } & \text { laporan } \\
\text { kejadian } & \text { tahun } \\
2015 & \end{array}$ & $\begin{array}{l}\text { login,menambahkan data } \\
\text { kejadian, melihat laporan } \\
\text { data kejadian, mencetak } \\
\text { laporan data kejadian }\end{array}$ & Berhasil & \\
\hline
\end{tabular}

Dari dua pengujian yang dilakukan, dihasilkan bahwa semua fungsi yang ada pada sistem aplikasi sensus penduduk tersebut berjalan sesuai yang diharapkan dan antar fungsi terdapat saling terhubung dengan baik.

\section{KESIMPULAN DAN SARAN}

\section{A. Kesimpulan}

Dari hasil pembuatan aplikasi sensus penduduk untuk desa Wulunggunung tersebut, maka dapat disimpulkan hal-hal sebagai berikut.

1) Aplikasi sensus penduduk ini dapat mempermudah para perangkat desa untuk melakukan hal yang berkaitan dengan kependudukan seperti pendataan penduduk, pembuatan surat keterangan dan pembuatan laporan kependudukan.

2) Aplikasi sensus penduduk ini dibuat dengan menggunakan IDE Delphi dan dapat berjalan dengan baik pada sistem operasi Windows XP ataupun diatasnya. Pengguna cukup memindahkan file-file aplikasi kedalam desktop tujuan beserta aplikasi penunjang lainnya seperti Xampp dan file basis data yang digunakan dalam Xampp.

3) Berdasarkan pengujian unit pada aplikasi sensus penduduk ini dengan menggunakan metode black-box, dapat disimpulkan bahwa fungsi-fungsi yang tersedia didalam sistem telah berjalan dengan baik sesuai dengan yang diharapkan.

\section{B. Saran} berikut:

Saran yang dapat diberikan oleh penulis adalah sebagai

1) Aplikasi yang sudah dibuat sudah berjalan dengan baik sesuai dengan tujuan, namun masih perlu dilakukan penelitian lanjutan untuk pengembangan aplikasi ini.

2) Penambahan fungsi-fungsi tertentu pada aplikasi ini agar memenuhi komponen-komponen secara lengkap dalam melakukan sensus penduduk.

3) Keamanan pada aplikasi ini masih kurang karena pada login tidak ada level tertentu dalam penggunaan aplikasi ini melainkan hanya ada level admin saja dalam pengoperasiannya.

\section{DAFTAR PUSTAKA}

[1] Bell, C. (2012). Expert MySQL. Apress.

[2] Jogiyanto. 2005. Analisis dan Desain Sistem Informasi. Yogyakarta: Penerbit Andi.

[3] ---,Wulunggunung-Sawangan-Magelang, http://blogdesa.id/desaku/profil/wulunggunung-sawanganmagelang, 4 Februari 2015.

[4] Tubagus Faisal A.Sistem Informasi Jasa Pelayanan Kependudukan Pada Kelurahan Krapyak Semarang Dengan Menggunakan Delphi, SKRIPSI-S1,Universitas Stikubank,Semarang,2013.

NEGARA KHUSUS, Universitas Syiah Kuala,Banda Aceh,2012. 